Questions vives

\section{Questions Vives}

Recherches en éducation

$\mathbf{N}^{\circ} 32 \mid 2019$

L'accueil et la formation linguistique des migrants. Quelles pratiques aujourd'hui?

\title{
"I dream of a better future to help my mother, to give her back all she gave to me...": social mobility projects, the family and other determinants in children's migration
}

"Je rêve d'une meilleure vie pour aider ma maman, pour lui rendre tout ce qu'elle m'a donné" : projets de mobilité sociale, la famille et autres déterminants dans les migrations des mineurs non accompagnés marocains vers l'Espagne

\section{Sofia Laíz Moreira}

\section{(2) OpenEdition}

Electronic version

URL: http://journals.openedition.org/questionsvives/4142

DOI: 10.4000/questionsvives.4142

ISSN: $1775-433 \mathrm{X}$

Publisher

Université Aix-Marseille (AMU)

Printed version

Date of publication: 30 December 2019

ISBN: 978-2-912643-56-8

ISSN: 1635-4079

\section{Electronic reference}

Sofia Laíz Moreira, "'I dream of a better future to help my mother, to give her back all she gave to me...": social mobility projects, the family and other determinants in children's migration", Questions Vives [Online], N $\mathrm{N}^{\circ} 32$ | 2019, Online since 30 October 2020, connection on 25 January 2021. URL: http:// journals.openedition.org/questionsvives/4142 ; DOI: https://doi.org/10.4000/questionsvives.4142

This text was automatically generated on 25 January 2021.

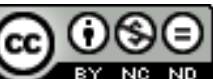

Questions Vives est mis à disposition selon les termes de la licence Creative Commons Attribution Pas d'Utilisation Commerciale - Pas de Modification 4.0 International. 


\section{"I dream of a better future to help my mother, to give her back all she gave to me...": social mobility projects, the family and other determinants in children's migration}

"Je rêve d'une meilleure vie pour aider ma maman, pour lui rendre tout ce qu'elle m'a donné" : projets de mobilité sociale, la famille et autres déterminants dans les migrations des mineurs non accompagnés marocains vers l'Espagne

Sofia Laíz Moreira

\section{Introduction}

1 Global inequalities, among other structural factors, have actively contributed to "the expulsion of productive future generations" (Coma \& Quiroga, 2005). Child migrations appear as an undesired effect of migration control policies in Europe, which has led to the repositioning of migrants' territorial mobility to penetrate within the European space (Vacchiano \& Jiménez, 2011).

2 The aim of this paper is to contribute to the understanding of child migration from a transnational and multisided perspective. For this purpose, the study has taken into account not only those structural patterns but also other symbolic elements like family and community solidarity and reciprocity dynamics that usually influence a child's migration project.

3 The conclusions reached in this analysis result from research conducted between 2010 and 2015, the main aim of which was to analyze the intergenerational mobility strategies of young migrants in Spain. The research focused on Moroccan youngsters 
(unaccompanied children as well as second generations of migrants) as agents of social mobility.

4 As part of this broader research work, this paper will focus particularly on the study of the migrations of unaccompanied children (from now on, UC) fostered in the Galician Child Protection Services. To better define the territorial scope of the research and provide a basis for a case study, the investigation has focused in particular on a specific context of origin: the province of Beni Mellal in Morocco. For this reason, an extensive field survey in the host and origin societies has sought to provide a more in-depth view of those life stories of youngsters from this specific area, including interviews with non-migrant relatives living in their hometowns.

5 This research has focused on four key elements that seem to shape Beni Mellal's child migration flows: i) the particular characteristics of a rural-based context of origin; ii) the rigidity of the family structure in a particular social and cultural system; iii) the pivotal role of transnational kinship networks in the activation of children's social agency, iv) the interrelation of institutional, legal and political structures that results in their segmented incorporation within the host society.

6 For this aim, the investigation develops an analysis of children's pathways prior to and following institutionalization processes within the Child Protection system. It attempts to discover those strategies pursued by young migrants to achieve personal and financial independence, and it examines how the protection system influences them. To this end, this paper has considered two main profiles: unaccompanied children and "separated children". Nevertheless, and for this analysis, we will refer to all of them as part of the category of "unaccompanied children", without distinction.

\section{Methodology}

7 The methodology strategy included a combination of quantitative and qualitative methods: a sample of 24 unaccompanied minors was included in the quantitative survey. A multisided ethnography technique was also applied, conducting in-depth interviews and life stories with 12 unaccompanied youngsters during the period in which they were fostered in the Galician Protection facilities. An intergenerational approach to investigate those family dynamics behind a child's migration project was also targeted. The technique of participant observation was completed with life stories to family members in the place of origin, which enabled a full immersion in the migrants' families' universe. Its aim was to gain a close and intimate familiarity with a given group of individuals (such as a religious, occupational, sub-cultural group, or a particular community) and their practices through intensive involvement with people in their own cultural environment, usually over an extended period of time (Bernard, 1998). To do so, several stays were arranged in the migrants' families' homes, since by taking part in everyday life the observer may truly get access to the lives of those being studied. To enable a further comparative analysis, surveys and in-depth interviews with minors from other Moroccan outward migration regions (Tanger, Nador, Tetuan) have also been undertaken within the Spanish context.

8 Two main questions have provided the focus for this research work:

- What is the role played by a child's migration project within his or her own community/ group of origin? 
- How are children's projects linked and influenced by the institutional and structural framework in which they are immersed (homeland and host society)?

9 A combination of qualitative and quantitative methodologies has been used. A survey was conducted among $54 \%$ of the whole registered population of UC fostered by the Galician government in 2010. In the qualitative research, twelve life stories were included among Moroccan UC youngsters. An ethnographical and multisided approach was applied at the same time, involving an extensive field survey at the place of origin and at the place of destination. Sample selection was therefore based on a diversity criterion, taking into account the following variables:

- the town/city of settlement in Galicia;

- the type of migration;

- the presence of other family references at the place of settlement. The total sample was finally composed of seven life stories of minors from towns and villages of Beni Mellal province and five others from other Moroccan towns involved in outbound migrations to Spain.

10 This diversifying approach enabled the analysis of two aspects relevant for understanding child migration : on the one hand, in the assessment of the impact of institutional protections as well as of the conditions of access to them, and on the other hand, in the comparison of different migratory routes and particular aspects of Beni Mellal children's migrations.

\section{Children from Beni Mellal}

11 When searching for the first unaccompanied children (UC) arriving mainly in Spain, official records lead us to the late 1990s. The first UC were registered in southern Spanish towns and in the Canary Islands. Within the international arena, the Spanish case shows particular trends as it has certainly shown a rapid growth rate in comparison to other European host countries (Senovilla Hernández, 2007).

With regard to the case of Galicia, 2006 appears as the first year of the presence of UC within the regional institutional services. Exceptionally high numbers were recorded in 2007 within the Galician protection services facilities (Laíz, 2011, 2012). Most of these arrivals were related to the redistribution of the UC population in different less overcrowded Spanish protection systems, as institutions in the southern regions seemed to be at a breaking point. Despite this, field surveys show how most of the UC from Beni Mellal arrived in Galicia with the support of other kinship networks, while children from other Moroccan regions show more erratic and longer pathways, with no family support in the place of settlement.

Nonetheless, Beni Mellal migrations to Spain take us back to the 1980s. This region comprising the territory located at the foothills of the Central Atlas is one of the largest outbound migration regions in the Moroccan scenario. Historically, the Moroccan map has shown outbound flows divided between two main pathways: from northern and Atlantic larger cities (Tanger, Nador, Tetuan and Casablanca) and mainly directed towards central European countries (Belgium, the Netherlands, Germany), and from central and southern Moroccan regions, heading for the Mediterranean European countries (France initially, and post-1980's in Italy, primarily, later in Spain). 

Plains region", is locally known as the "triangle of death" and is delimited by the urban nodes of Beni Mellal, Khouribfa and Kelâa Sraghna. When identifying the main destination places in Spain, most informants agree on small villages and suburbs surrounding the cities of Alicante, Valencia, Murcia, Cádiz, Jerez de la Frontera, Benidorm or Córdoba. internal and international migrations. Migration history has built up a fund of popular knowledge generated from the experiences of families and neighbours, shaping a true cultural value and know-how around the idea of migration. Transnational kinship networks have spread between Italy, Spain and France shaping true transnational family circuits, where members move from one European city to another in the search for better job opportunities. This migration culture, forged from the echoes of past stories, has given birth to a collective imaginary where the Harraga becomes prince. El Dorado has become the goal of nearly every family in the surrounding area, with a particular impact on young generations. Migration has become a sign of social status and family prestige in the sense that migration has gradually represented the main strategy for achieving quicker and more impressive social mobility.

\section{Linking family, kinship networks and institutional structure in the host society}

Amina Bargach, an expert in Moroccan child migration, emphasizes the need to understand that the children's projects include a life plan based on a combination of their own individual goals and additional family expectations (Bargach, 2009). Accordingly, child migration should be interpreted as involving a multiplicity of interconnected emotional,rational and pragmatic decisions.

17 When approaching the study of children's projects, the analysis of other family members' expectations and support for minors' migration projects become essential elements for the understanding of a child's goals. As explained by Castles, migration appears as a strategy to fulfil the desires, expectations and projections of the family but also those of a community (Castles, 2002). This perspective leads us to study the links between three interrelated systems: family, kinship networks and the Child Protection system.

18 Nevertheless, we cannot forget the role of cultural background as it explains the differences in the perception of what an "adult" means in different cultural contexts, as youngsters in Morocco are soon considered adults while they are still considered minors in an occidental context.

19 On the other hand, the Moroccan family exhibits a specific organizational schema which is based on strong and complex ties of solidarity and reciprocity between community members, as well as on gendered hierarchies, which impact on the possibilities of migration. Women's migrations, for this reason, seem to depend on men's decisions :

"If you want to go. ¿migrating? if your husband says yes, ok so. You can ask him to go with him, if not, you cannot go. That's all. Cause they have the money; they decide who goes. Maybe his brother will go, because he is a man, because he is more powerful, he can deal with it, women can't, because they don't work".

Questions Vives, $N^{\circ} 32$ | 2019 
(Focus group with six women of a rural village, aged from 17 to 40 years old, Ouled Youssef, Beni Mellal Province, Morocco, 2012)

"Only eldest sisters can go, or those who have married a man living there. If you decide by yourself, they won't let you go, your brothers won't let you go. Family and religion are always first".

(UC's sister, 21 years old, Beni Mellal city,Morocco, 2012)

El Harras (2004) explained how "reciprocity of supportive exchanges between parents and children resist considerably to the development of individual calculations", especially in more traditional contexts where there still prevail vertical and utilitarian intergenerational relationships between parents and children, as is the case in rural settings.

"They go there to obtain their papers, they go there to search for a better future, to have a good life and prosperity, and they also go there to help those who stay here". (UC's sister, 16 years old. Ouled Youssef village, Beni Mellal Province,Morocco, 2012) "I'm going to help my mother because she is the one who worked and raised us". (UC, 17 years old, taken in care by the Galician Protection System, A Coruña, Spain, 2011) concerning the analysis of the modernity/tradition binary, where lies the genesis of stereotypes regarding rural undeveloped social behaviours, which could support an undesirably evolutionary approach in the interpretation of those changes that may be generated with regard to migrants.

It seems therefore necessary to analyze children's migrations from a broad multidisciplinary perspective, taking into account cultural, social and structural aspects. Based on the work by Jimenez (2011) on Moroccan child migration, we argue that we should apply a transnational approach which places the migrant child within a larger relational structure that transcends borders. This idea is based on the recognition of kinship networks as active members of a child's migration project, as actors that place the child as the core element of a transnational system where complex interrelations take place. This dynamic reveals a number of expectations based on common and individual interests which come to life through the operation of principles of reciprocity, solidarity and cooperation between members.

"I would like him to stay working there and then help us a little bit, if he is well there in Spain, he can have a job, then he can help us, because here it is very difficult, I'm all alone, his father is ill, he cannot work, we are alone. He is going but he will not forget us. I'm alone here working with three children. Ahmed, when he saw his father ill, he said: "I have to help my mother" and he decided to go himself to Spain".

(UC's mother, 39 years old, food shop owner. Beni Mellal City, Morocco, 2012)

"most things I do, I don't do them for me, I dream of a better future to help my mother, to give her back all she gave to me..."

(Former UC, 18 years old, from Beni Mellal, taken in care by the Galician Protection System. A Coruña, Spain, 2013)

The migrant child is being placed indeed as linking actor of this multilateral connection system involving communitarian and individual aims. We can also observe how these migrations work as a way of producing development in rural and poor areas in Morocco, where the young migrant plays the role of financial support for his family left behind. other (from nuclear family to extended family and child protection service) reveals 
how the initial expectations framed prior to a child's migration are later focused on the results obtained. Hence, when a child remains within the extended family sphere, these obligations are due to other family members. It has been observed how different tensions take place between dislocated kinship cells revealing a clash of interests between different actors. The contradictions between one kinship cell and the other (origin and destination family members) are brought to light when the migrant youngster is persuaded or obliged to become a financial support for the host group economy to the detriment of his own best possible development, which most of the time implies dropping out from school and abandoning the educational pathways. Interestingly, it has also been observed how educational pathways were limited by immigration policy restrictions, being strongly impacted when a child remained outside the protection system. Research revealed that the maintenance of residence permits, when the child is unprotected, inevitably blocked educational goals, with youngsters restrained from planning a long-term educational pathway due to job placement requirements to ensure the extension of their residence permit.

With regard to those children fostered by the public Child Protection services, the different uses of the available resources with UC children and the nature of the institutional system have resulted in segmented project outcomes, when out of the protection system.

"You know, foreign affairs authority, they are not good with us. I don't know if it is a matter of law or if they simply drawn, because they don't care about us, they just think we are animals, but we are people! They live here, they have their family here, they have their house, their job, they don't care about what happen to us. But earth is of all of us, you know? And we are people. I'm living in the streets, I have no home, and they (police) come and hit us, shout at us, as we were dogs. Now I had to get married to get my papers. It cannot be a prison, if they want us to go away; they have to give us the documentation, the permits to go to another country. They just say "rejected". I just want to have my permits to go to France, I have my family there".

(Former UC, 19 years old, from Tagzirt, village, Beni Mellal Province (Morocco). A Coruña, Spain,2013)

As verbatim records show, some former UC mostly ended in a quite vulnerable situation when split off the protection system after 18. Most of them argued a lack of support to accede to housing and food when they were from one day to the next left outside the foster homes, with no job and no legal documentation. In the following paragraph, a detailed analysis will illustrate the factors that explain these situations, which represented a worrying number of cases.

\section{The impact of institutionalization: young migrants channelled into segmented pathways}

UC educational pathways are traced by a combination of personal choices but are strongly influenced by Spanish common law (education law) as well as special legal mandates: immigration law, the protocol for unaccompanied minors, among others (Alonso \& Laiz, 2012).

28 In Galicia, the main guidelines regarding the treatment of children within the Protection System are provided by the Individualized Education Project (PEI). This document is drawn up on the basis of the child's choices and the child's individual 
needs. In the case of unaccompanied immigrant children, although the child's age of entry in the protection system may justify attempting his/her integration within the Compulsory Secondary Education system (ESO), the results obtained in the survey conducted with children in residential care centres in 2010 revealed that most UC showed serious difficulties in keeping up with high school courses. These difficulties were especially linked to the lack of basic knowledge (25\%) and lack of command of the two official languages in Galicia, Spanish and Galician (54.2\%).

The same survey also showed that more than half of the sample cases (58\%) were not receiving any vocational training at all, enrolment in the ESO educational system being prioritized. On the other hand, children who were older than the compulsory education age threshold (16) and were able to access the personal independence programme, named "Mentor" programme, had applied for membership and had no response $(41.7 \%)$.

Even though an ESO educational level certainly gives access to technical training courses (intermediate vocational training), its continuation after threshold age is not advisable when the student is not improving but being delayed in his or her professional pathway. Meanwhile, while the point of view of the authorities supports the idea that a common pathway provides the basis for equal access opportunities, access to higher education can also be obtained through the Initial Professional Qualification Programmes (PCPI), already enabling the candidate to learn skills for a specific job. This second alternative represents a more suitable choice in phase with the UC's personal project and urgent needs related to his financial independence before the age of 18 , which also helps with regard to the goal of achieving the residence permit extension requirements as soon as possible.

31 Moreover, the real institutional failure arises when a young adult has neither succeeded in obtaining a minimum ESO level nor obtained a specific professional training diploma when reaching adulthood. This again focuses again the discussion on the question of how protection systems can determine equal access to higher education pathways or filter off some children towards underqualified pathways.

32 Cases of greater concern, however, were identified regarding those young migrants (12.5\%) who had not received any formal training since their registration within the protection services because they were still not provided with legal documentation, despite being already taken into care more than nine months previously (the legal deadline for the regularization of minors under public care). The explanation for this situation is related to children's age of arrival in the protection system close to the age of adulthood, being usually excluded from assistance as their legal residence rights have expired, in other words, the time needed for obtaining the residence permit was higher than the time left to become subject of the immigration law and no more of child protection laws, becoming illegal individuals and adults. This is unfortunately also applicable to those cases of minors who have already been institutionalized in other Spanish communities - in confirmed cases, for more than five years - and that due to the lack of coordination between regional authorities, their eligibility to be subject of protection has just "run out of time".

Interestingly, outcomes of UC personal independence pathways show three main directions:

- Those that have acceded to a protection "extension": after the age of 18, Galician law allows the possibility of an extension of the assistance period up to the age of 21 . Although cases 
that benefit from these three additional years are exceptional, extra institutional support may be a decisive for emancipation determinant. Not only because of the legal extension within the institutional system, but because they can have the benefit of social capital that can help them to find an entry to the labour market, as well as increase their human capital. Despite this, only a few of UC included in this research had received an extension of residential and technical assistance. These same cases were the same as those that succeeded in acceding to the labour market and subsequently maintained their legal status. Whatever the access conditions may be, what seems to be more important is to consider youngsters' need to gain real personal and financial independence. In the case of UC and migrant children, this is a very difficult achievement due to the lack of useful social capital to help them have access to the "formal" labour market.

- Those who have succeeded profited from a vacancy in the assistance programme, showing the strong impact on minors' personal independence projects. This resource provides fostered children with a monitored training pathway for the purposes of accessing the labour market. Apart from housing facilities, youngsters can benefit from institutional networks to find a job. Accordingly, results confirmed that when the candidate is not able to access professional networks provided by institutional channels, the socio-economic independence project usually fails. Thus, the results of such educational pathways - in the light of the situation of the Spanish labour market crisis at the time of survey's realization presented a bleak picture.

- Those who have been excluded from further support and immediately expelled at the age of eighteen have had no access to professional networks or further financial support. These young adults, now considered outside the scope of the child protection system's bureaucratic and administrative structure, call into question the liability of the protection systems $l$ and their responsibility with regard to the outcome for the personal independence of protected children. Thus, the same candidate benefitting from protection one day is barred from support and falls under immigration law the day after. Findings show a bewildered young adult, unemployed and close to or already in an irregular legal situation, excluded from access to housing, work or any social assistance as within a few months after leaving the foster center they fall into an illegal status.

The results shown all along this research have brought into light the consequences of an unprepared child protection system which couldn't afford appropriate responses to UC's needs but also, the great contrast between the migration imaginary that has pushed youngsters to migrate and the real situation that they found in Spain:

"It also has to do with legal documentation. I was living in the streets; if I stay in this foster home, I can possibly obtain my papers and receive some training. I would like to do welding or work as a mechanic; I've already done these jobs at home. I was in Madrid, so I've just worked in the market, I had no papers, nothing... sometimes I used to have some illusions, now I don't' have many, I lost them along the way,...people talk a lot about Spain at home, I really don't see such a difference now".

(Former UC, 18 years old, taken in care as unaccompanied minor by the Galician Protection System, from Beni Mellal Province (Morocco). Ferrol, Spain, 2013.)

\section{Conclusions}

The above results confirm that the problem of unaccompanied migrant youth is largely explained by the functioning of the assistance measures. While family and community may explain the goals and direction of a child's migration project, the combination of 
structural determinants together with local policies will determine, to a larger extent, the outcome which will be achieved on the pathway to social incorporation.

Findings have shown how important it is to consider broader social systems that consider the migrant child a social agent within a family and social structure. In this way, the followed pathways are being shaped by the interaction of general policies (education and employment) and specific ones (Child Protection regional law, Unaccompanied Minors Protocol and immigration law) (Alonso \& Laiz, 2012). Likewise, research has revealed that it is not possible to understand the phenomenon of migration without understanding certain cultural elements in the worldview and past history of the children. It is unarguably essential to consider not only individual but also group strategies behind child migration as well as the complex interrelations that take place within the transnational social system that connects family and communitarian members on either side.

Immigrant youngsters' pathways are being clearly conditioned by Child Protection and educational policies with radically different results depending on the type of resources accessed. The impact of institutionalization can therefore determine a young adult's social inclusion/exclusion. We have already seen how support measures interact and influence differentially youngsters' post-institutional situation. Moreover, it seems necessary to regulate the criteria for access to additional institutional support in order to avoid discriminatory outcomes.

In the case of Galicia, a mismatch has been observed between training policy and employment opportunities upon leaving the institutional system. Integration Outcomes after institutionalization seem to be closely linked to the resources (human and social capital) accessed during the period of institutional protection. Clearly, in the case of a UC, rapidly deploying all possible tools is thus a matter of urgency in order to help with their effective social incorporation

\section{BIBLIOGRAPHY}

We thus identify the position of the migrant child as potential social agent within legal, political and social structures that push him downwards in the social hierarchy. We therefore make an appeal for a mediating role of protection systems in the child's integration process, asserting its responsibility for guaranteeing the fulfilment of fundamental rights and access to equal opportunities in order to avoid segmented incorporation within the host society.Alonso, P. \& Laiz, S. (2012). Trayectorias de los jóvenes migrantes de Beni Mellal en Galicia: una mirada desde la política educativa con alumnado extranjero. Workshop "La inmigración marroquí: miradas a origen y destino", Universidad de Navarra.

Bargach, A. (2009). La integración del menor migrante sin referente adulto en el país receptor. En A. Jiménez Hernández (Eds.) Menores migrantes sin referentes familiares (pp. 29-34). Granada: Grupo Editorial Universitario. 
Berriane, M. (2004). La larga historia de la diáspora marroquí. In B. Lopez y M. Berriane (Eds.), Atlas de la inmigración marroquí en España (pp. 24-26). Madrid: Universidad Autónoma de Madrid y Ministerio de Trabajo y Asuntos Sociales.

Bernard, H.R. (1998). Participant observation. In H. R. Bernard (Ed.), Handbook of methods in cultural anthropology (pp. 259-299). Walnut Creek, CA: AltaMira Press.

Castles, S. (2002). Migration and community formation under conditions of globalization. International migration review, 36(4), 1143-1168.

Coma, M. \& Quiroga, V. (2005). Menors que emigren sols del Marroc a Catalunya. Barcelona: Editorial Mediterrània.

ONU (2006). Convention on the Rights of the Child. (https://www.ohchr.org/en/professionalinterest/ pages/crc.aspx).

Duvivier, E. (2010). Entre installation et poursuite de la mobilité. Analyse des trajectoires postinstitutionnelles des jeunes isolés étrangers accueillis à l'Aide Sociale à l'enfance. Revue Migration et Société, 22(129-130), 243-255.

El Harras, M. (2004). Marruecos, la diversificación de las estructuras y relaciones familiares (pp. 34-36). In B. López y M. Berriane (Eds.), Atlas de la inmigración marroquí. Madrid : UAM.

Jiménez Álvarez, M. (2011). Intrusos en la fortaleza: menores marroquíes migrantes en la frontera sur de Europa. Thèse de doctorat inédite.

Laíz Moreira, S. (2011). La situación y tratamiento institucional de Los jóvenes migrantes no acompañados en Galicia: ¿hacia una emancipación? Revista sobre la infancia y la adolescencia, (1), 72-85.

Laíz Moreira, S. (2012). Famille, communauté et transnationalisme. Migrations des mineurs marocains vers l'Espagne : le cas de Béni Mellal. Hommes \& migrations. Revue française de référence sur les dynamiques migratoires, (1300), 62-71.

Laíz Moreira, S. (2015). L'impact de l'institution dans les processus d'émancipation des mineurs migrants de Beni Mellal (Maroc) en Galice (Espagne). Revue européenne des migrations internationales, 31(2), $79-96$.

Moujoud, N. (2011) Effets de la migration sur les femmes et sur les rapports sociaux de sexe. Audelà des visions binaires, Les cahiers du CEDREF, 57-79.

Massey, D \& Aysa, M. (2005). Social capital and international migration from Latin America, Expert group meeting on international migration and development in Latin America and the Caribbean population division. Department of Economic and Social Affairs. United Nations Secretariat, Mexico City, 30 November - 2 December 2005.

Senovilla Hernández, D. (2007). Situación y tratamiento de los menores extranjeros no acompañados en Europa: los casos francés, alemán, italiano y británico. In F. Legaz (Ed.), Observatorio Internacional de Justicia Juvenil, Bélgica.

Vacchiano, F. \& Jiménez, M. (2011). De “dependientes" a "protagonistas”. Los menores como sujetos migratorios. In N. Ribas Mateos (Ed.), El río Bravo Mediterráneo (pp. 495-511). Madrid: Editorial Bellaterra.

Vacchiano, F. \& Jiménez, M. (2012). Between agency and repression: Moroccan children on the edge. Children's Geographies, 10(4), 457-471.

UNICEF (2005). Nouveau visage de la migration. Les mineurs non accompagnés. Analyse transnationale du phénomène migratoire des mineurs marocaines vers l'Espagne. Rabat : Unicef Maroc. 


\section{ABSTRACTS}

The migration of children has caught the attention of the social science research community in recent years. The institutional treatment of unaccompanied children in European host societies has been widely discussed as it concerns a social actor combining several legal profiles: that of an unprotected child and that of an irregular migrant. This paper aims at presenting the results of the research work conducted between 2010 et 2015 with unaccompanied children fostered in the child protection services system of the Autonomous Community of Galicia in Spain. By applying a combined methodology and a multi-site ethnographical field survey, the study has drawn upon different members of children's kinship networks and key informants to discover the premigration determinants and relational processes that are involved in children's migration projects. The study reveals how the combined effects of different social actors and public policies influence and determine the framing and results of a child's migration process, normally leading to segmented incorporation within the host society.

Les migrations d'enfants ont retenu l'attention de la communauté scientifique durant les dernières années. Le traitement institutionnel des mineurs non accompagnés dans les sociétés européennes a été largement discuté car il fait référence à un acteur social qui combine différents profils légaux : le mineur sans protection ainsi que le migrant en situation irrégulière. Cet article présente les résultats d'une recherche qui a été menée entre 2010 et 2015 avec des mineurs non accompagnés accueillis dans des structures de protection de l'enfance de la communauté autonome de Galice, en Espagne. Grâce à une méthodologie combinée et en se basant sur une enquête de type ethnographique et multi-située, le travail de terrain a pu inclure différents membres des réseaux familiaux ainsi que des informateurs clés, dans l'objectif de découvrir les facteurs pré-migratoires et relationnels qui expliquent les migrations des mineurs. Cette recherche a apporté un éclairage sur la façon dont la combinaison des différents acteurs sociaux et des politiques publiques peut déterminer le cadre et les résultats des projets migratoires des mineurs. Les conclusions montrent que dans la majorité des cas, ils révèlent d'une incorporation segmentée dans la société d'installation.

\section{INDEX}

Mots-clés: mineurs non accompagnés, migrations marocaines, politiques d'intégration, Beni Mellal, Espagne

Keywords: UC migrations, Moroccan migrations, integration policies, Beni Mellal, Spain

\section{AUTHOR}

\section{SOFIA LAÍZ MOREIRA}

Docteure en sociologie,

LAMES et TELEMME

CNRS, Aix Marseille université 